\title{
The Relative Abundance, Distribution and Species Diversity of Phytoplanktons in Kanye Dam in Kano, North western- Nigeria
}

\author{
${ }^{1}$ Abdullahi. Y., Mustapha, Y., Indabawa, I. I and Sindama, A \\ Department of Biological Science Federal University Kashere, Nigeria \\ ${ }^{2,3}$ Department of Plant Biology, Bayero University Kano Nigeria \\ ${ }^{4}$ Department of Biological Sciences, Federal University Wukari, Nigeria
}

\begin{abstract}
The abundance and distribution of phytoplankton algae of Kanye Reservoir was studied from Five (5) sampling sites for the period of five (5) Months and analysed for Physico - chemical attributes such as Temperature, pH, Dissolved Oxygen, Biological Oxygen Demand; Nitrogen-Nitrate, Phosphorus-Phosphate and Electrical Conductivity using standard methods. Results showed that the physico- chemical characteristics recorded was that of a typical tropical region. The highest cell count $\left(8.8 \times 10^{4}\right)$ cells $/ \mathrm{ml}$ was recorded in Site ' $E$ ', followed by site 'A' $\left(6.4 \times 10^{4} \mathrm{cells} / \mathrm{ml}\right)$, the least was recorded in site ' $C$ ' $\left(8.3 \times 10^{3} \mathrm{cells} / \mathrm{ml}\right)$ Physico-chemical attribute did not vary significantly among the sites. Four (4) Classes of Algae were identified which was dominated by Chlorophyta 23(46\%), followed by Baccilariophyta 20,(40\%), Cyanophyceae 5,(10\%) with poor representation of the Harmful types by three (3) species namely: Microcystis aeruginosa, Oscillatoria princeps and Anabaena circinalis with a total cell count $\left(9.6 \times 10^{3} \mathrm{cells} / \mathrm{ml}\right)$ less than $2 \times 10^{4} \mathrm{Cells} / \mathrm{ml}$, there was generally high number of algal cells observed during the wet season than in the dry season. However, Oscillatoria princeps was identified with the highest number of occurrence in both site ' $B$ ' and ' $E$ ' $\left(4.9 \times 10^{3} \mathrm{cell} / \mathrm{s} / \mathrm{ml}\right)$ followed by Microcystis aeruginosa and Anabaena cercinalis identified at site ' $E$ ' and 'A' $\left(1.6 \times 10^{3} \mathrm{cells} / \mathrm{ml}\right.$ and the class with the least number of species was Euglenopyta 2, (4\%). L. there was a positive significant correlation between algae and physicochemical attributes of the reservoir. The study showed that the reservoir is not polluted and the water is safe for domestic use since the number of harmful algal cells recorded is relatively low which is within the WHO standard for safe water
\end{abstract}

Keywords: Planktonic, Kanye, Tropical, Reservoir, Polluted, Harmful, WHO, Cyanophyceae.

\section{Introduction}

Water reservoirs and Dams are major water resources, which are very diverse both in terms of size and fisheries potential. The relationship between the physico-chemical parameters and Phytoplankton production of water bodies are of great importance in management strategies of aquatic ecosystems. Reserviour and ponds are often used for domestic and agricultural purposes therefore the quality of the water may be described according to their physico-chemical and phytoplankton characteristics. Phytoplankton, because of their role as primary producers in an aquatic ecosystem are the subject of great interest and their qualitative and quantitative estimates can provide good indices of quality and productive capacity of water in tropical reservoirs, though some species on the other hand can be harmful to human and animals by releasing toxic substances (hepatotoxins or neurotoxin etc) into the water (Sigee 2004) Phytoplankton are recognised worldwide as bioindicators organisms in the aquatic environment (Underwood, et al.,1999)

\section{Study Area}

\section{Materials and Methods}

Kanye Dam is located in the Sudan savanna zone of Northern Nigeria on latitude $11^{\circ} 57^{\prime} \mathrm{N}$ and longitude $8^{\circ} .1^{\prime} \mathrm{E}$ with two distinct seasons (wet and dry). The rainy season lasts from May to October while the dry season lasts from November to April. Kanye Dam is approximately $50 \mathrm{~km}$ away from Kano, along Kano-Gwarzo road in Kabo Local Government Area of Kano State, and about $11.25 \mathrm{~km}$ from Kabo town. It has an area of $11.31 \mathrm{~km}^{2}$. It was constructed in 1969 and commissioned in 1970. The dam was constructed for agricultural purposes (such as irrigation, fisheries, forestation), domestic uses and to control flooding. The Dam has a total storage capacity of 24.60 million cubic meters, active storage capacity of 21.53 million cubic meters and dead storage capacity of about 3.07 million cubic meters (RSMP, 1982). It has two major sources these are river Guzu-Guzu and river Kanyan maja. 


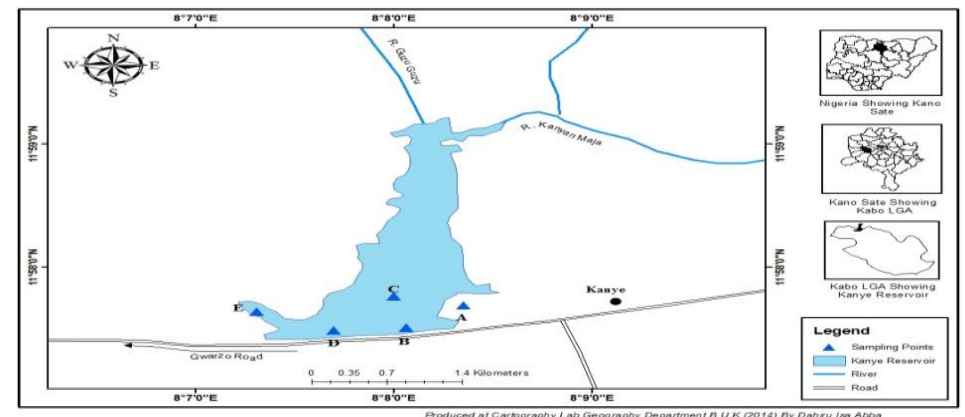

Figure 1: Map of Kano Showing the Study Area and Sampling Sites

\section{Sampling sites}

The sampling site was divided in (5) sampling locations namely: sites A, B, C, D and E they were selected based on intensity/type of anthropogenic activities. GPS 12 model (GRAMIN, USA) was used in taking the global position of the sites as follows:

Site A: This is an enclosure that is directly linked with the dam about $30 \mathrm{~m}$ to the inshore of the dam. At this site human activities like farming, washing, bathing, were taking place and is located at Lat $11^{\circ} 57^{\prime} 32.02^{\prime \prime} \mathrm{N}$ and Long $8^{\circ} 08^{\prime} 25.13^{\prime \prime} \mathrm{E}$.

Site B: Point B is the inshore of the Dam. Washing, bathing, Irrigation and fishing were taking place at the site and is located at Lat $11^{\circ} 57^{\prime} 31.79^{\prime \prime} \mathrm{N}$ and Long $8^{\circ} 08^{\prime} 21.59^{\prime \prime} \mathrm{E}$.

Site C: This is the midshore of the Dam, it is the middle of dam, only fishing was found to be taking place at the site, it is considered to be deepest part of the dam. And is located at Lat $11^{\circ} 57^{\prime} 31.09^{\prime \prime} \mathrm{N}$ and Long $8^{\circ} 08^{\prime}$ 07.93"E.

Site D: Site D is the outlet of the dam, where water is taken to the treatment plant through a pipe, human activities like bathing also take place at the site. It is located at Lat $11^{\circ} 57^{\prime} 28.33^{\prime \prime} \mathrm{N}$ and Long $8^{\circ} 08^{\prime} 07.91^{\prime \prime E}$.

Site E: This is the offshore of the Dam where fishing, huge agricultural/farming activities were taking place; this is where possibly the water and other algal communities may be influenced by the chemical substances from surface runoff. Washing and bathing are frequent at this sampling site. It is located at Lat $11^{\circ} 57^{\prime} 23.74 " \mathrm{~N}$, and Long $08^{\circ} 07^{\prime} 22.02^{\prime \prime}$.

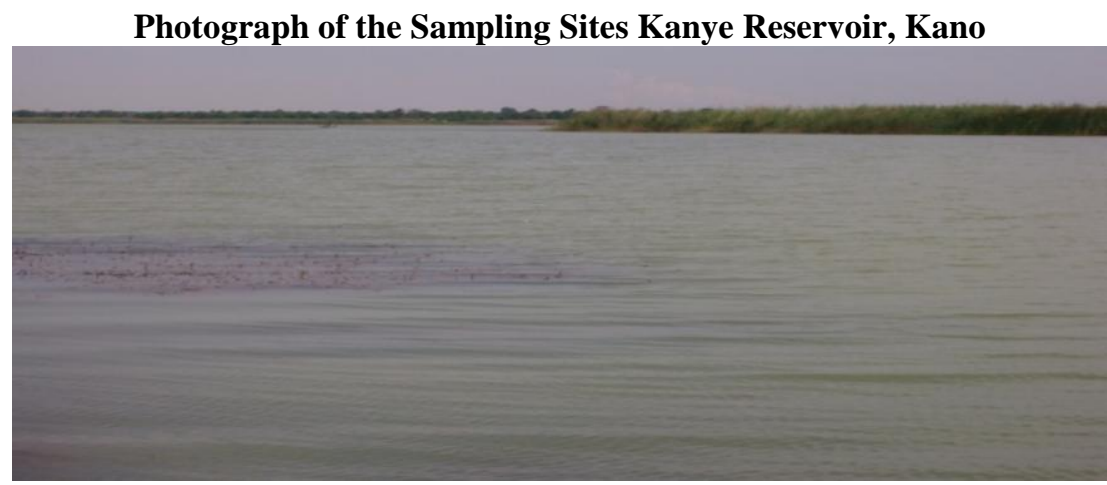

Figbure 2: A general view of the Kanye Dam

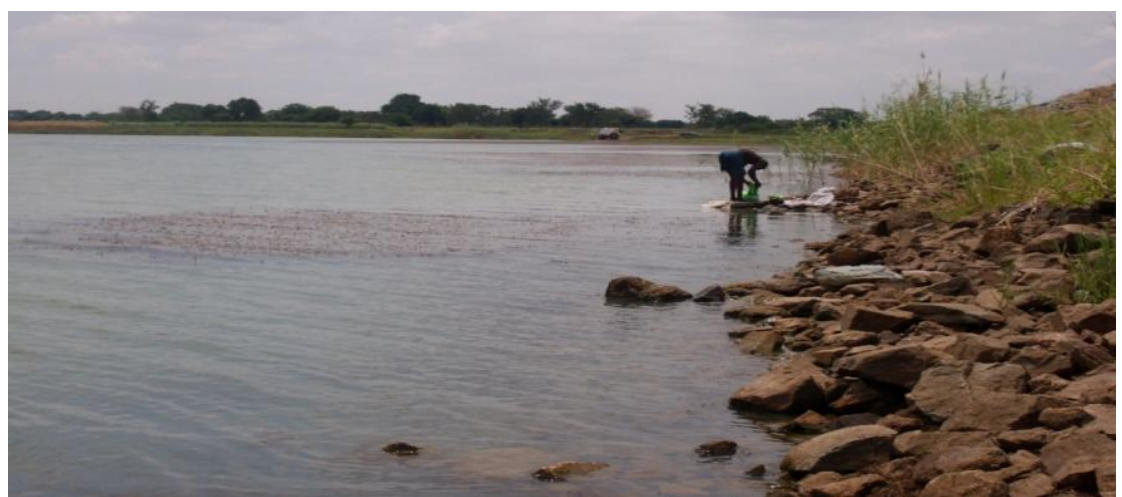

Figure 3: Kanye Dam showing the rocky bank where anthropogenic activities take Place 
The Relative Abundance, Distribution and Species Diversity of Phytoplanktons in Kanye Dam in ..

\section{Collection of Water Samples}

All surface water samples were collected between 7 - 8am from the months of March-August 2013and analysed either in the field (in situ) or within six hours in the laboratory. Surface water Temperature was determined in situ with mercury in glass thermometer (Fisher S- 41624 model) graduated in units of ${ }^{\circ} \mathrm{C}$ as described by Offem, et al., (2009). pH was determined using dip in mobile battery pH meter as described by (APHA, 1999) Dissolved Oxygen was determined using Hach 7021Model Jenway Dissolved Oxygen Meter as described by (APHA, 1999). Biological Oxygen Demand $\left(\mathrm{BOD}_{5}\right)$ was determined after 5 days incubation method as described by (APHA, 1999) The Nitrogen- nitrate was determined using portable data logging spectrophotometer Hach DR/2010 model. Phosphorus-phosphate $\left(\mathrm{PO}_{4}{ }^{3-}\right)$ : The concentration of phosphate was also determined using portable data logging spectrophotometer Hach DR/2010 model. The Electrical conductivity was determined using conductivity meter (Hach- CO 150/2010) as described by APHA (1999).

\section{Collection of Phytoplankton}

Phytoplanktons were collected using plankton net of mesh size $55 \mu \mathrm{m}$ towed at low speed for $10 \mathrm{~min}$ and immediately collected in screw capped bottles and immediately fixed with $4 \%$ formalin. This was transferred to the laboratory in ice packed container prior to identification.

\section{Identification of Algae}

The water samples containing the algae were centrifuged in the laboratory at 1500rpm for 30minutes using centrifuge machine model (Merlin 502000). A portion of each of the sample was examined with the aid of microscope. This was carried out using a UNICO binocular microscope in the laboratory. Photomicrographs were made, using a photomicroscope, to further aid identification. References on identification of species of algae were made to that of Patrick and Reimer (1975), Needham and Needham (1962), Prescott (1961), Watanabe et al., (1995) and Kadiri (1996).

\section{Result}

\section{Result and Discussion}

A total of fifty (50) different algal species identified was recorded during the period of study which was of four Taxa: Bacillariophyta, Chlorophyta, Cyanophyta and Euglenophyta. Chlorophyta had 23, (46\%), Bacillariophyta 20, (40\%), Euglenophyta 2, (4\%) and Cyanophyta 5, (10\%). Three (3) out of the five (5) species of Cyanophyta identified were classified harmful in nature. There was relatively high algal cell count recorded in site ' $\mathrm{E}$ ' with a total of $\left(8.8 \times 10^{4} \mathrm{cell} / \mathrm{ml}\right)$, followed by site ' $\mathrm{A}$ ' with $\left(6.4 \times 10^{4} \mathrm{cell} / \mathrm{s} / \mathrm{ml}\right)$ and the least was recorded in site ' $\mathrm{C}$ ' with $\left(8.3 \times 10^{3}\right.$ algal cell/ml). The highest cell count recorded in site $\mathrm{E}$ could be attributed to eutrophication as a result of runoff from neighbouring farmland and discharge in to the water body. Site ' $\mathrm{C}$ 'and ' $\mathrm{D}$ ' recorded a relatively low algal cell count, this could be due to relatively fewer activities taking place at both sites. Site 'B' recorded higher algal cell than site 'C' and ' $D$ '. The number of algae identified correlate with the values of physico-chemical parameters recorded and the activities taking place at the various sampling sites.

It was also observed that the algae were recorded in higher densities in the rainy season than in the dry season, this contradict the findings of (Indabawa and Abdullahi 2004) who recorded higher algal cells in the dry season than in the rainy season. The dominance of Chlorophyta recorded in this study is a typical of most African waters (Kadiri 1996). The relatively high Chlorophyta algal cell recorded during the period of study could be due to increase in nutrient content of the dam leading to the development of phytoplankton as observed by (Kilhem and Hecky; 1988).However the abundance of Bacillariophyta (diatoms) is also interesting, since it has also been reported in other fresh water environment (Kadiri 1993), (Ezra et al., 2008). Euglenophyta and Cyanophyta were poorly represented as $4 \%$ and $10 \%$ of the total algal cells which are two groups of Eutrophic or nutrient rich water bodies (Calgon and Conforti, 1991). Their poor representations could be as a result of the poor nutrient status of Kanye Reservoir. A reasonable number of desmids were also recorded as they are inhabitants of oligotrophic (nutrients poor) water bodies as reported by Kadiri (2003). The surface water temperature influences most of the physical, chemical and biological characteristics of water bodies. The highest mean temperature value was recorded at site 'A' and ' $\mathrm{D}$ ' $\left(25.83^{\circ} \mathrm{C}\right)$ while the least was recorded at site 'B' $\left(25.25^{\circ} \mathrm{C}\right)$. The result also indicates that temperature has significant correlation with Nitrate, Phosphate and Electrical conductivity at $0.01 \%$ level of significance. It also correlates with the abundance and distribution of algae. In site 'E' as the temperature increased Oscillatioria cells decreases from $\left(3.3 \times 10^{3}\right.$ to $1.6 \times 10^{3}$ cells $\left./ \mathrm{ml}\right)$. The high mean values of temperature recorded at site 'A' and 'B' could be associated with high solar radiation, high evaporation and low rainfall, while the relatively low mean values of temperature recorded at site ' $\mathrm{B}$ ' could be due to low evaporation, low solar radiation and rainfall. It increased from March to April and decreased gradually through May to August. The pattern of temperature changes from dry to rainy season could be attributed to low solar radiation, low evaporation and rainfall. This agrees with the observation made by Ezra and Abdulhameed (1997). 
The mean physico-chemical attributes is recorded in Table 1 where the Surface Water Temperature during the period of study influenced the other physico-chemical and biological characteristics of water bodies. In this study the highest mean temperature value was recorded at site ' $A$ ' and ' $D$ ' $\left(25.83^{\circ} \mathrm{C}\right)$ while the least was recorded at site ' $\mathrm{B}$ ' $\left(25.25^{\circ} \mathrm{C}\right)$. This could be as a result of the variation in season result also indicates that temperature has significant correlation with nitrate, phosphate and electrical conductivity at $0.01 \%$ level significance. According to work of Ezra and Abdulhameed (1997), the high values of temperature recorded could be associated with high solar radiation, high evaporation and low rainfall, while the relatively low mean values of temperature recorded at site ' $\mathrm{B}$ ' could be due to low evaporation, low solar radiation and rainfall. Generally the temperatures during the period of study reflected that of tropical region. It increased from March to April and decreased gradually through May to August. The pattern of temperature changes from dry to rainy season could be attributed to low solar radiation, low evaporation and rainfall.

$\mathrm{pH}$ range of (8.2-8.7). Neutral or lower values in water decreases algal growth. WHO (2003) standard of $\mathrm{pH}$ range in fresh water is (7-9). In this study, the highest mean $\mathrm{pH}$ value was recorded in site ' $\mathrm{E}$ " (7.9) while the least was recorded in site ' $\mathrm{D}$ ' (7.6). The values of $\mathrm{pH}$ recorded in this study fall within the WHO (2003) standard and correlates positively significantly with electrical conductivity. The highest value of $\mathrm{pH}$ recorded could be attributed to run off from the neighbouring farm land as well as discharge into the water bodies. Similar observation was made in site A' which are the two sites that have direct influx from neighbouring farm land. This finding agrees with the findings of Antoine and Al-Sa'adi (1982) who associated the pH values recorded in their studies to run off from agricultural land.

The highest mean value for dissolved oxygen was recorded in site ' $A$ ' $(4.70 \mathrm{mg} / \mathrm{L})$ while the least was recorded in site ' $\mathrm{C}$ ' $(3.35 \mathrm{mg} / \mathrm{L})$. The result indicated a negative correlation with temperature and significant correlation with conductivity. This is not unconnected with the nature of anthropogenic activities taking place around sites ' $A$ ' and ' $E$ ' such as farming, washing and bathing. This agrees with the findings of Indabawa and Abdullahi (2004) who reported a DO of (0.51-9.25mg/L). Lind (1968) also reported seasonality of DO in two highland reservoirs that are influenced by runoff in the rainy season.

Nitrate and phosphates are the two most important factors contributing to eutrophication in water. The highest

mean nitrate value was recorded at site 'A' $(2.62 \mathrm{mg} / \mathrm{L})$ while the least was recorded at site ' $\mathrm{B}$ ' $(1.35 \mathrm{mg} / \mathrm{L})$. The

Table 1. Mean \pm SE in Physico-chemical Variations at Sampling Sites (A -E) of Kanye Dam Reserviour, Kano State

\begin{tabular}{|c|c|c|c|c|c|c|c|}
\hline Sites & $\begin{array}{c}\text { Temperature } \\
\left({ }^{\circ} \mathrm{C}\right)\end{array}$ & pH & $\underset{\left(\mathrm{mgL}^{-1}\right)}{\mathrm{DO}}$ & $\begin{array}{c}\text { BOD } \\
\left(\mathrm{mgL}^{-1}\right)\end{array}$ & $\begin{array}{l}\mathrm{N}-\mathrm{NO}_{3} \\
\left(\mathrm{mgL}^{-1}\right)\end{array}$ & $\begin{array}{l}\mathbf{P}^{-P O_{4}} \\
\left(\mathrm{mgL}^{-1}\right)\end{array}$ & $\begin{array}{c}\mathrm{EC} \\
(\mu \mathrm{S} / \mathrm{cm})\end{array}$ \\
\hline $\mathbf{A}$ & $25.8 \pm 0.6$ & $7.7 \pm 0.2$ & $4.7 \pm 0.9$ & $2.1 \pm 0.4$ & $2.6 \pm 1.2$ & $1.0 \pm 0.5$ & $612 \pm 39.1$ \\
\hline B & $25.5 \pm 0.6$ & $7.7 \pm 0.3$ & $3.4 \pm 0.4$ & $2.2 \pm 0.4$ & $1.4 \pm 0.7$ & $1.0 \pm 0.5$ & $625 \pm 42.4$ \\
\hline $\mathbf{C}$ & $25.3 \pm 0.6$ & $7.8 \pm 0.3$ & $3.4 \pm 0.4$ & $1.8 \pm 0.4$ & $1.6 \pm 0.9$ & $0.9 \pm 0.5$ & $606 \pm 47.3$ \\
\hline D & $25.8 \pm 0.6$ & $7.6 \pm 0.3$ & $3.3 \pm 0.4$ & $2.1 \pm 0.4$ & $1.8 \pm 1.2$ & $1.1 \pm 0.6$ & $623 \pm 51.5$ \\
\hline $\mathbf{E}$ & $25.7 \pm 0.8$ & $7.9 \pm 0.3$ & $3.7 \pm 0.6$ & $2.2 \pm 0.6$ & $2.0 \pm 1.1$ & $1.0 \pm 0.6$ & $626 \pm 45.7$ \\
\hline
\end{tabular}

Do $=$ Dissolved Oxygen, BOD = Biochemical Oxygen Demand, $\mathrm{P}-\mathrm{PO}_{4}=$ Phosphorus Phosphate, $\mathrm{N}_{-} \mathrm{NO}_{3}=$ Nitrogen Nitrate, EC $=$ Electrical

Conductivity

nitrate values recorded in this study fall within WHO (2003) limit. Nitrate values recorded positively correlate

with temperature and phosphate at $0.01 \%$ level significance. However, the values of Nitrate fluctuated with

variations in seasons. This could be attributed to the runoff from neighbouring farm land fed with inorganic

fertilizers by farmers, discharged in to the water bodies. Similar observation was made by Olaniyan (1969) and

Watanabe et al., (1995), who reported that nutrients are potential determinant of ultimate productivity, as

DOI: 10.9790/2402-1104012031 $\quad$ www.iosrjournals.org $\quad 23 \mid$ Page


The Relative Abundance, Distribution and Species Diversity of Phytoplanktons in Kanye Dam in ..

evidenced by many limnological studies correlating high nitrate and phosphate values to abundant phytoplankton flora. The Biochemical Oxygen Demand was within the W HO (2003)standard limits for BOD of unpolluted water is less than $5 \mathrm{mg} / \mathrm{L}$. The highest mean BOD value was recorded at site ' $\mathrm{E}$ ' $\left(2.23 \mathrm{mgL}^{-1}\right)$ while the least was recorded in site ' $\mathrm{C}$ ' $\left(1.77 \mathrm{mgL}^{-1}\right)$, the result indicated a significant negative correlation with $\mathrm{DO}$ and phosphate. The highest mean electrical conductivity value was recorded in site ' $E$ ' $(626 \mu \mathrm{S} / \mathrm{cm})$ while the least was $(606 \mu \mathrm{S} / \mathrm{cm})$ in site 'C' the values recorded in this study correlate significantly with temperature, and $\mathrm{pH}$. The EC values recorded also fluctuates with season due to different some human activities taking place in the Dam and discharge from surface run off. Similar observation was made by Adeniji (1993) and Sunda et al., (2006) in Shiroro Lake who reported a dry season mean conductivity attributed to higher concentration effect due to reduced water volume; however the higher conductivity of the water may be a pointer of eutrophication of the Dam.

\section{Some Cyanophyta Algal species Identified in Kanye Reservoir}

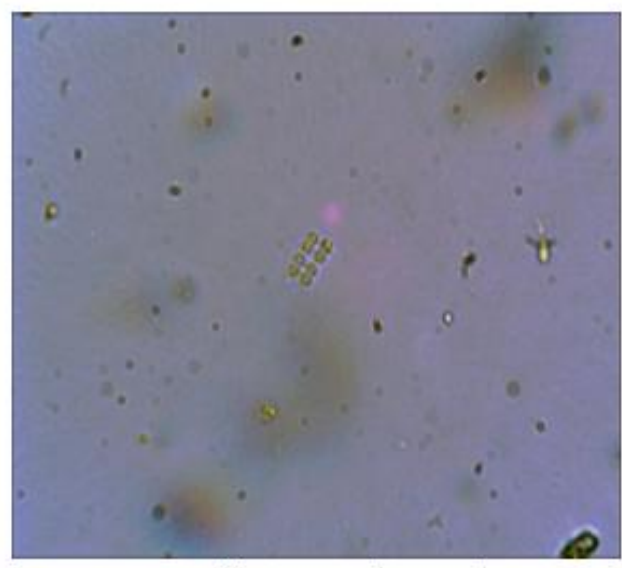

Agmenellum spp $(\times 600)$

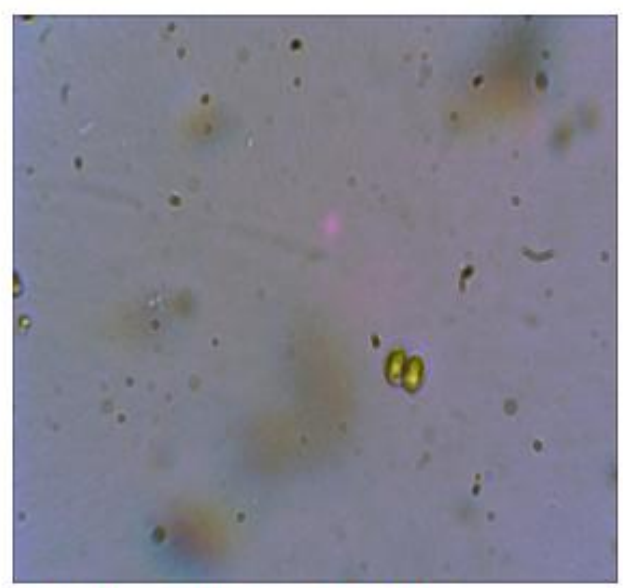

Chlorococcus spp $(\times 600)$

\section{Chlorophyta Algal species Identified in Kanye Reservoir}

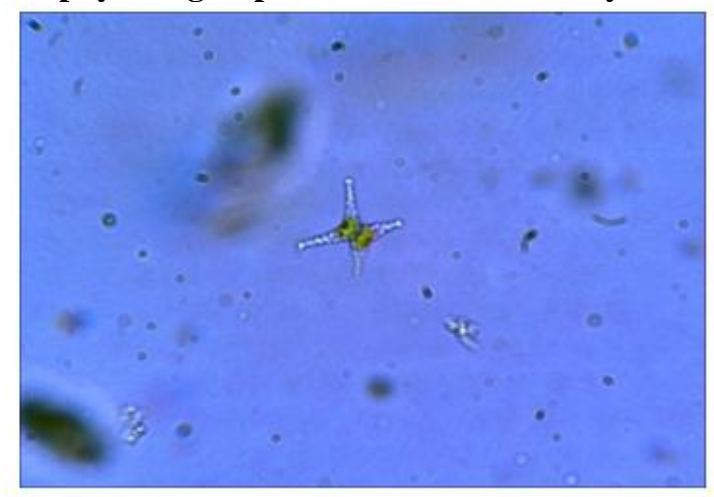

1: Akistrodesmus spp (×600)

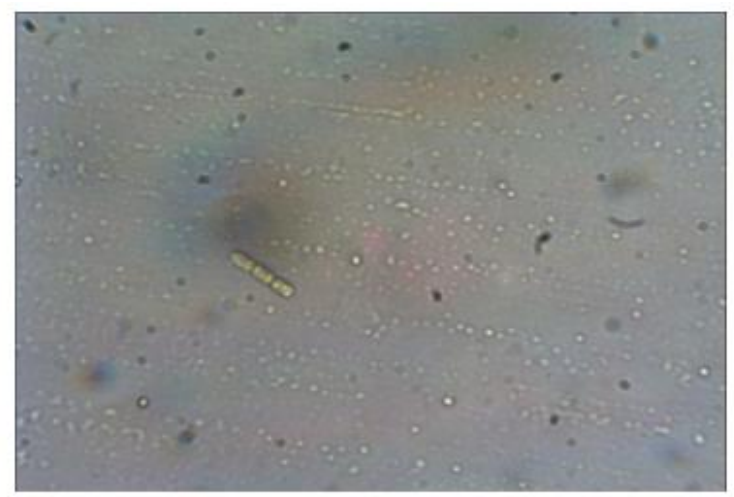

2: Chaetophora incrassata $(\times 600)$ 
The Relative Abundance, Distribution and Species Diversity of Phytoplanktons in Kanye Dam in ..

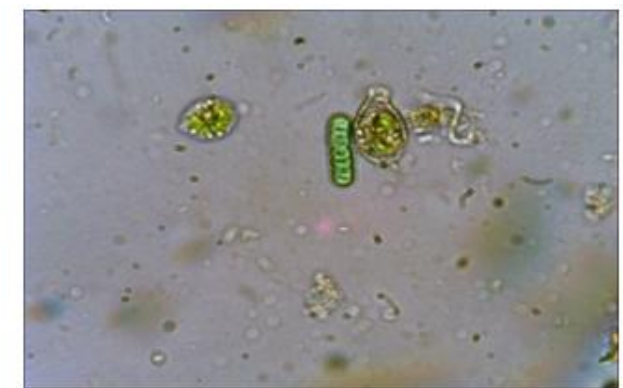

3: Chlorococcus spp $(\times 600)$

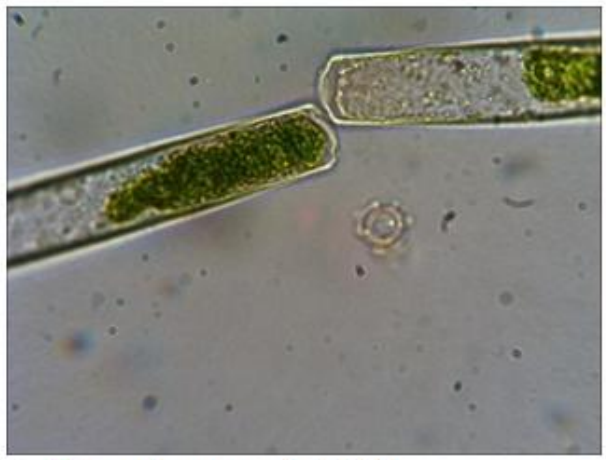

5: Closterium spp $(\times 600)$

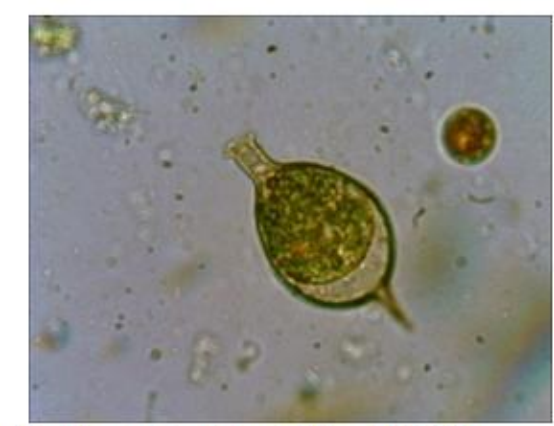

7: Characiopsis spinifer $(\times 600)$

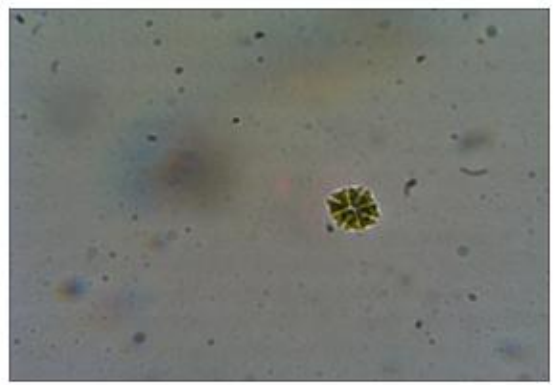

9: Micrasterias spp $(\times 600)$

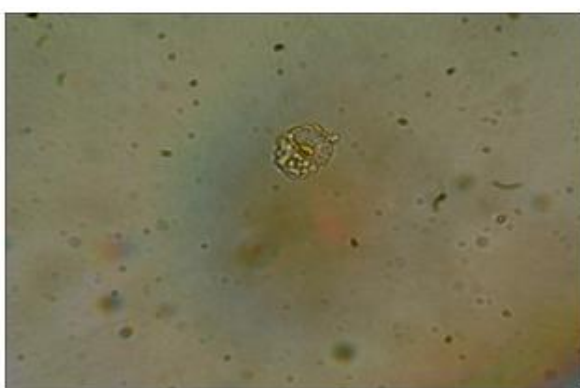

4: Cosmarium spp $(\times 600)$

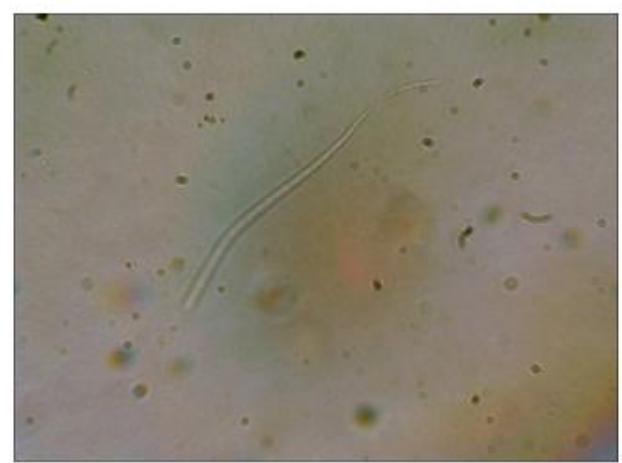

6: Chara spp $(\times 600)$

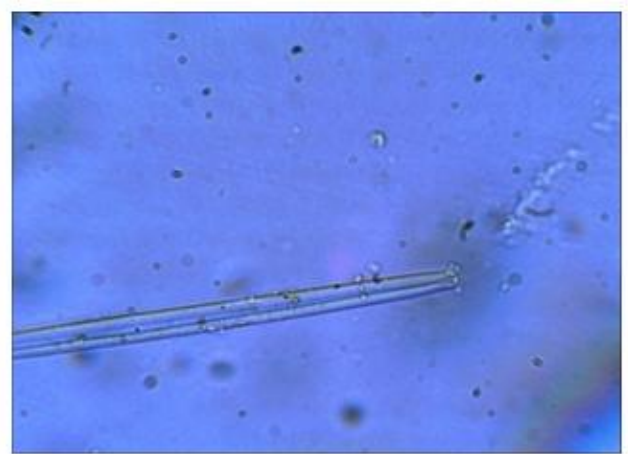

8: Cylindrocystis $\operatorname{spp}(\times 600)$

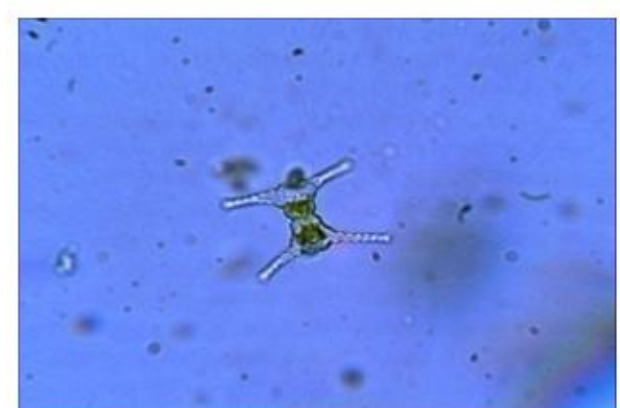

10: Mougeotia scalaris $(\times 600)$ 
The Relative Abundance, Distribution and Species Diversity of Phytoplanktons in Kanye Dam in ..

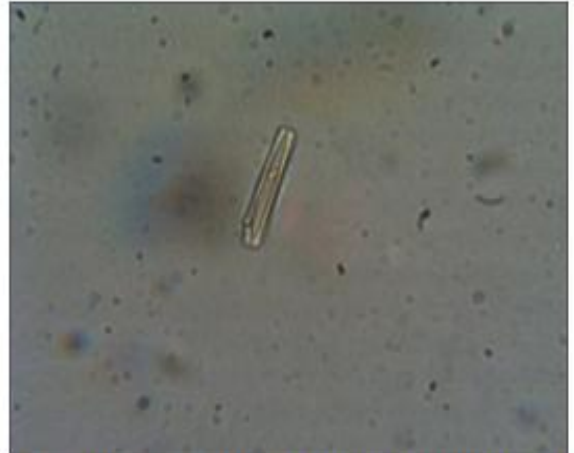

11: Plageotropis Lepidoptera $(\times 600)$

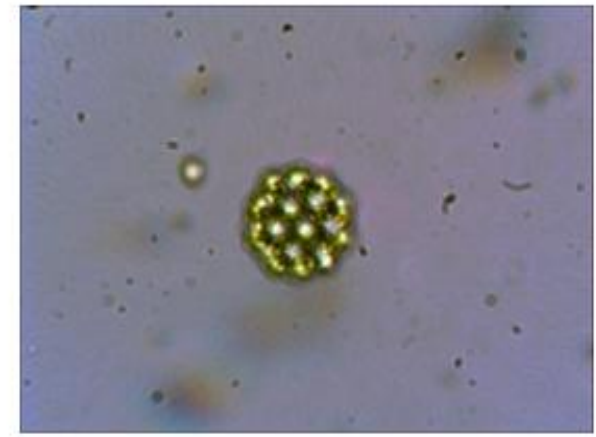

13: Pedistrum nauticum $(\times 600)$

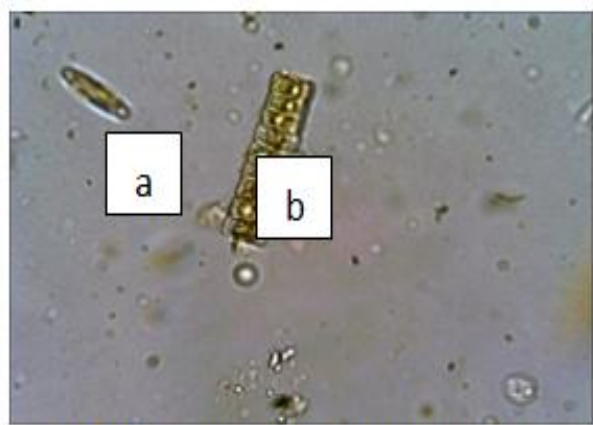

12: (a): Navicula ilopangoesis spp

(b). Zygnema $(\times 600)$

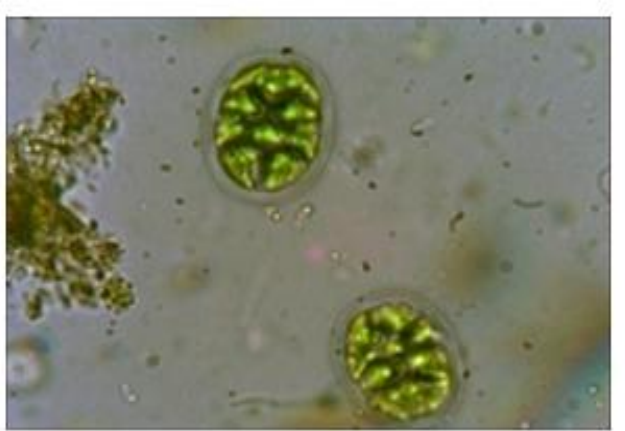

14: Pediastrum intergrum $(\times 600)$ 
The Relative Abundance, Distribution and Species Diversity of Phytoplanktons in Kanye Dam in ..

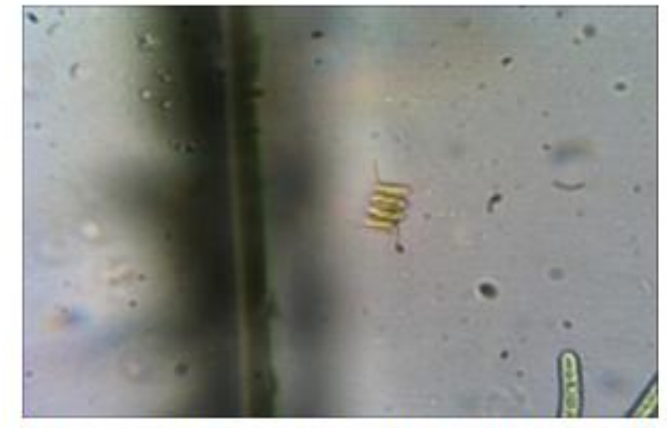

15: Scenedesmus quadricauda $(\times 600)$

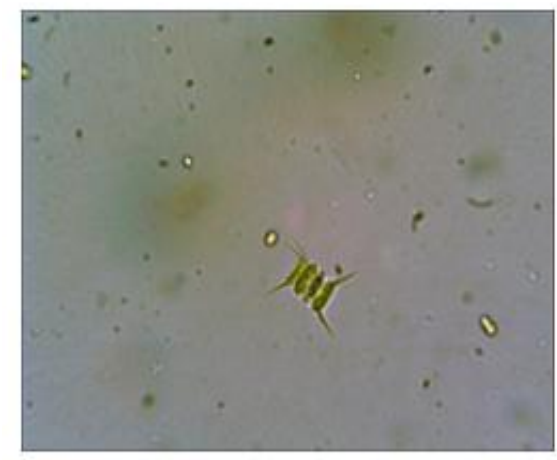

17: Scenedesmus quadricauda $(\times 600)$

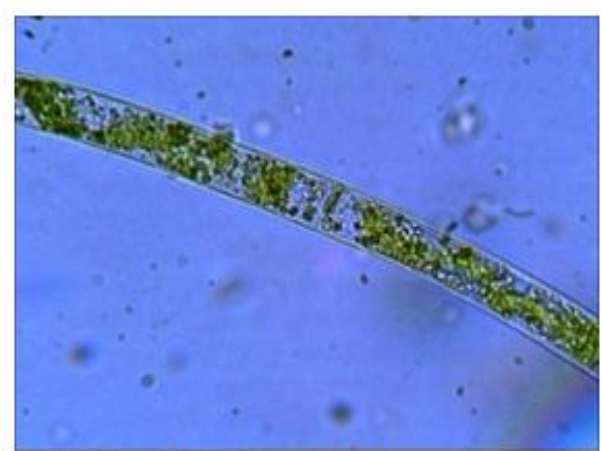

19: Spirogyra spp $(\times 600)$

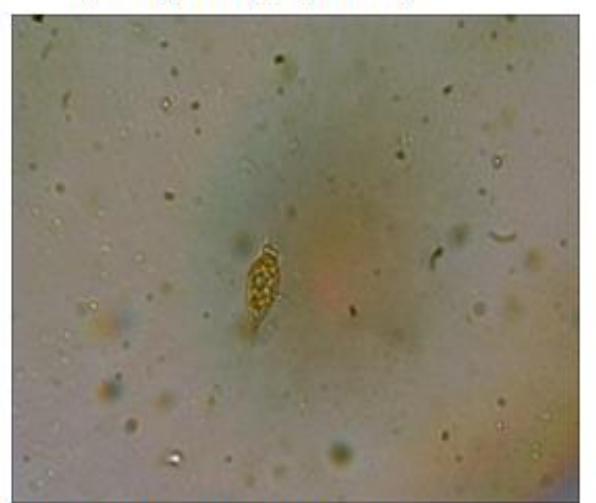

21: Phytoconeis botryoides $(\times 600)$

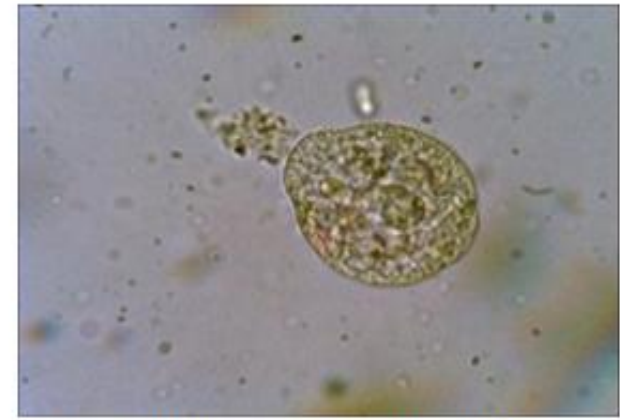

16: Tetraspora $\operatorname{spp}(\times 600)$

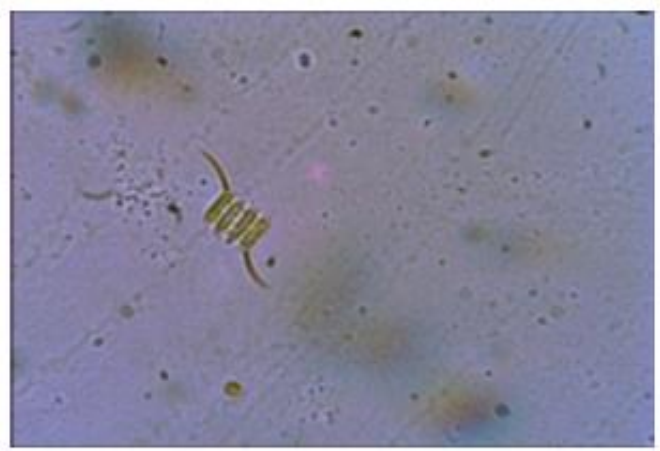

18: Scenedesmus bijuga $(\times 600)$
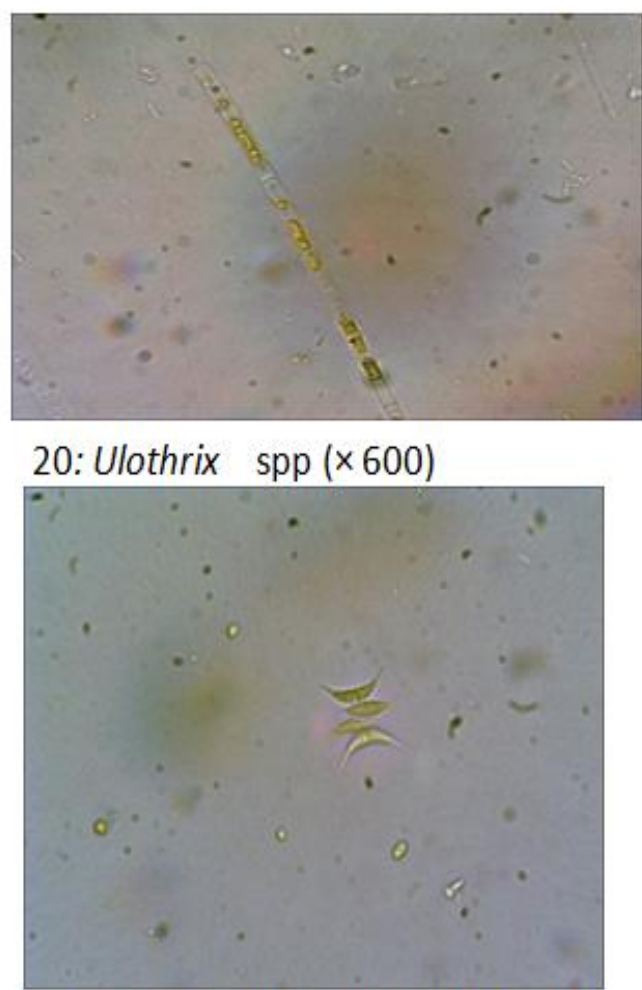

22: Characium limneticum $(\times 600)$ 


\section{Bacillariophyta}

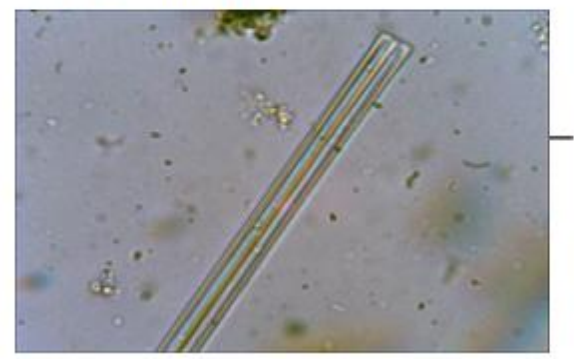

1: Asterionellaformosa $(\times 600)$

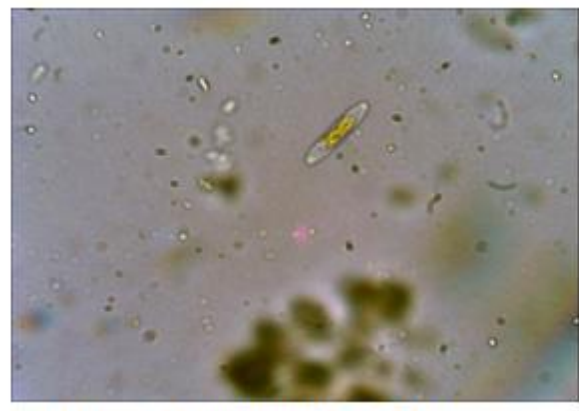

3: Diatoma vulgare $(\times 600)$

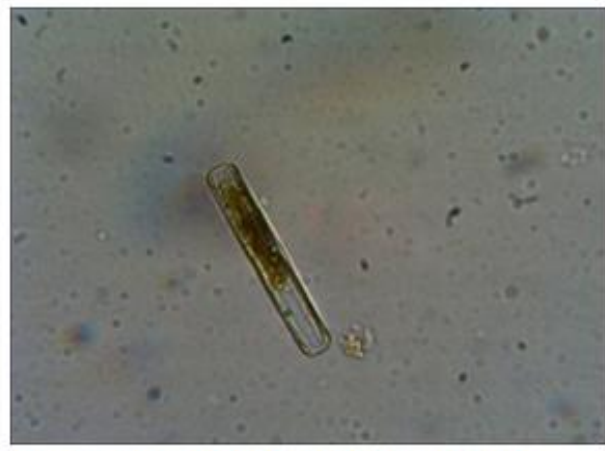

5: Denticula elegans $(\times 600)$

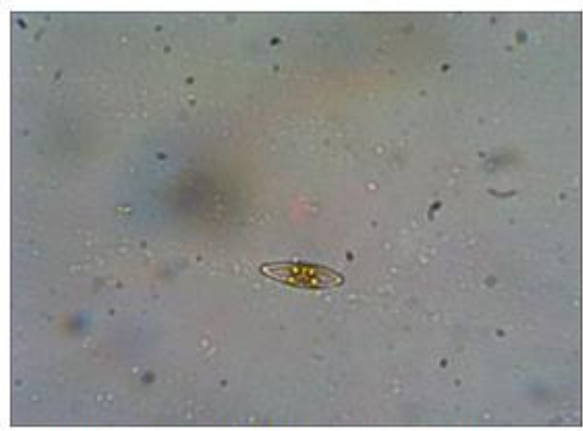

7: Navicula gastrum (×600)

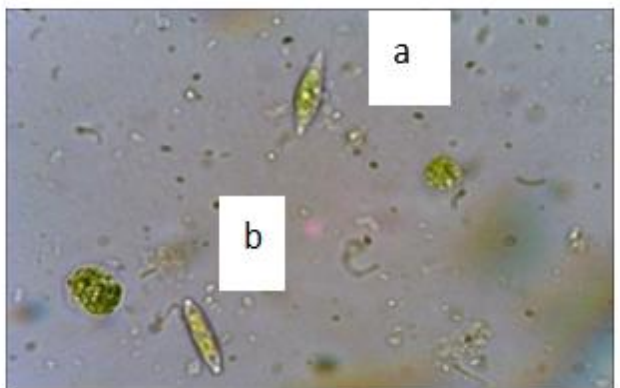

(a) Anomoenies serians (x 600)

(b) Stauronies $\operatorname{spp}(\times 600)$

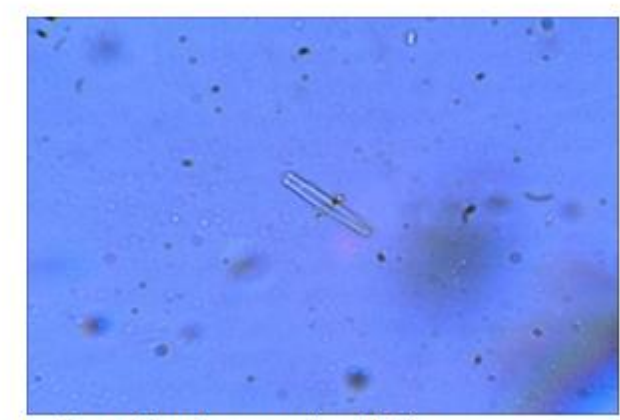

4:Denticula $\operatorname{spp}(\times 600)$

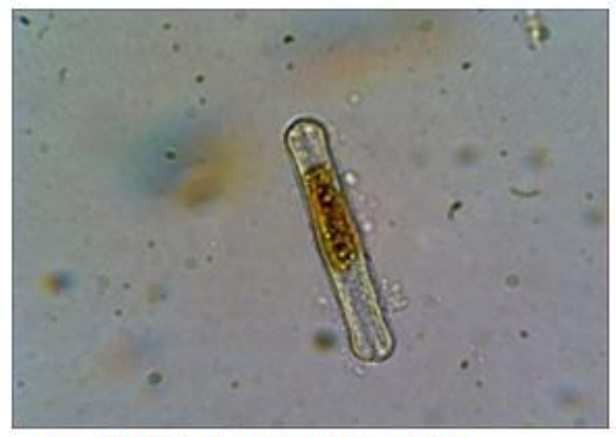

6: Melosira $\operatorname{spp}(\times 600)$

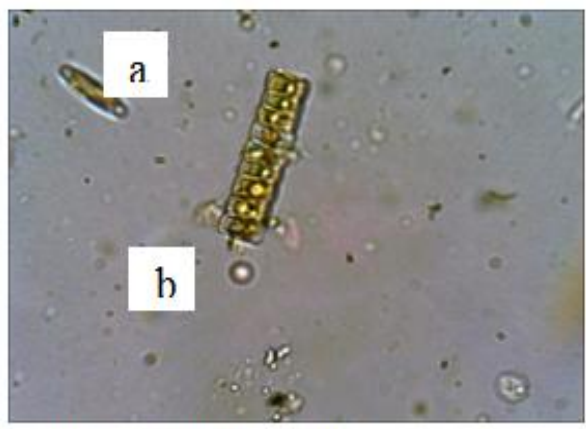

8: (a) Navicula ilopangoesis

(b) Zygnema spp $\times 600$ 


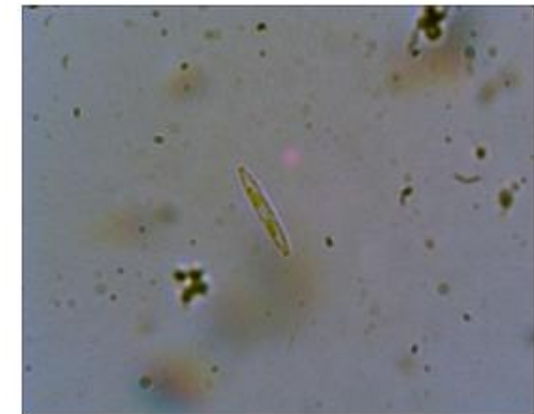

9: Navicula cuspidata cell $(\times 600)$

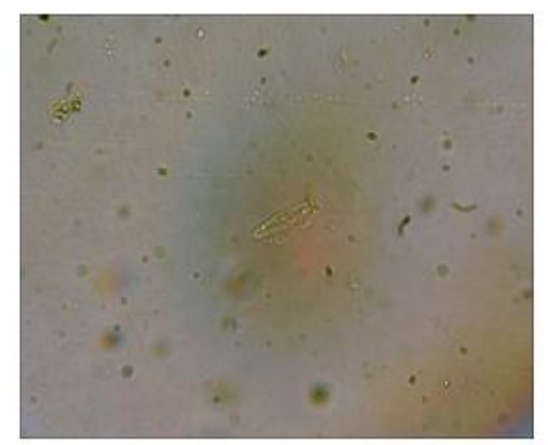

11: Navicula graciloides $(\times 600)$

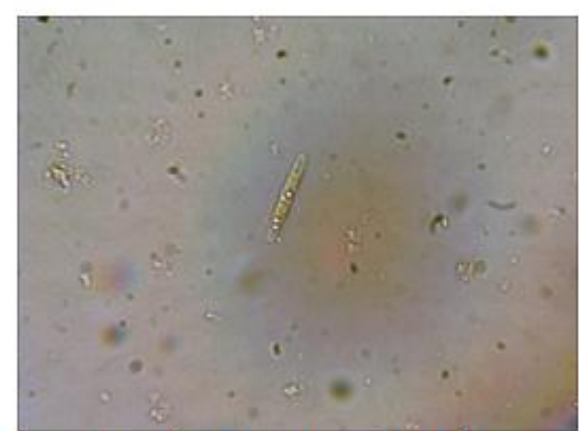

13: Pinnularia spp $(\times 600)$

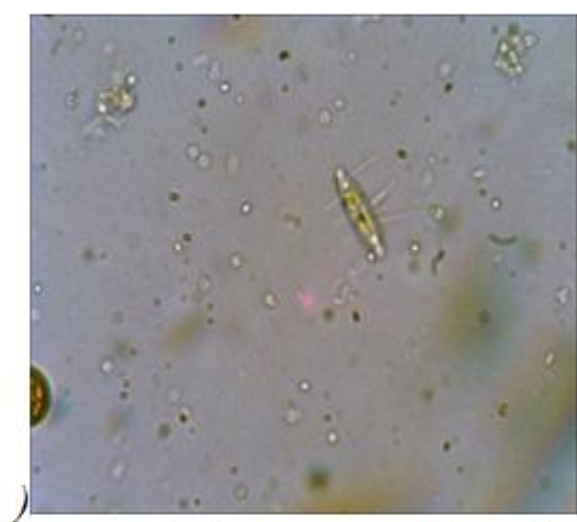

15: Cymbella angustata $(\times 600)$

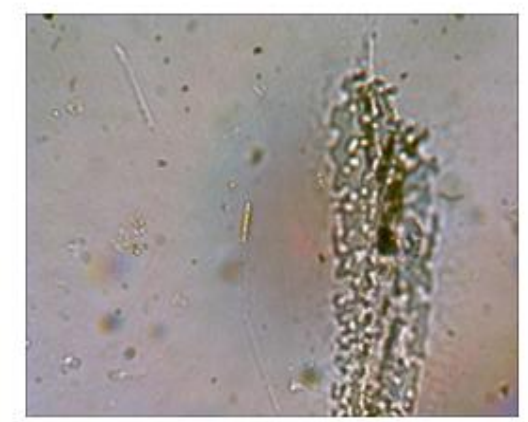

10: Navicula notha $(\times 600)$

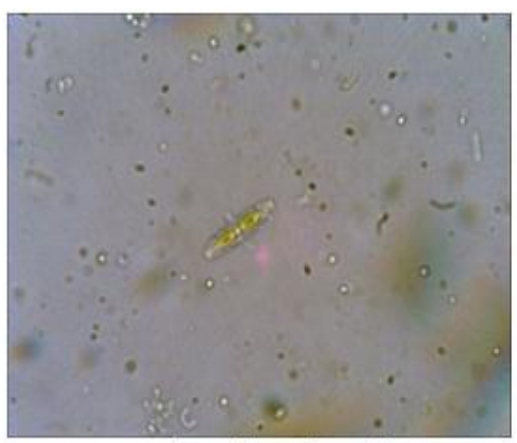

12: Frustuliarhomboides (× 600)

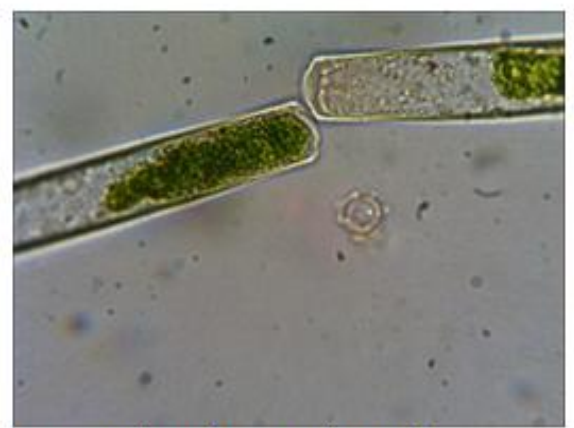

14: Cyclotella $\operatorname{spp}(\mathrm{x} 600)$

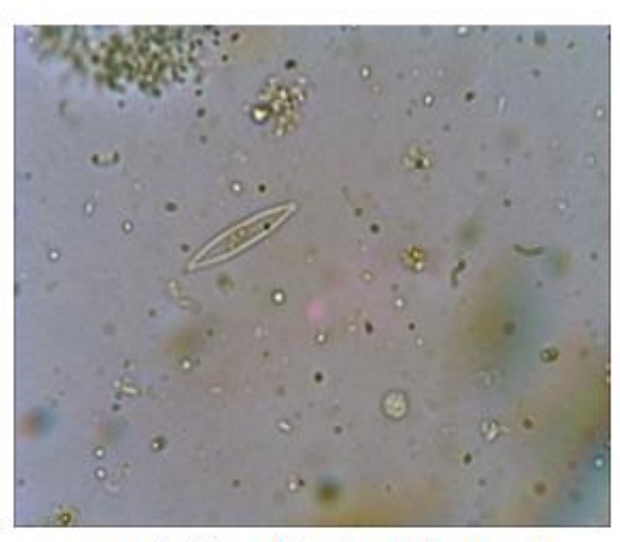

16: Cymbella diluviana $(\times 600)$

Single cell 


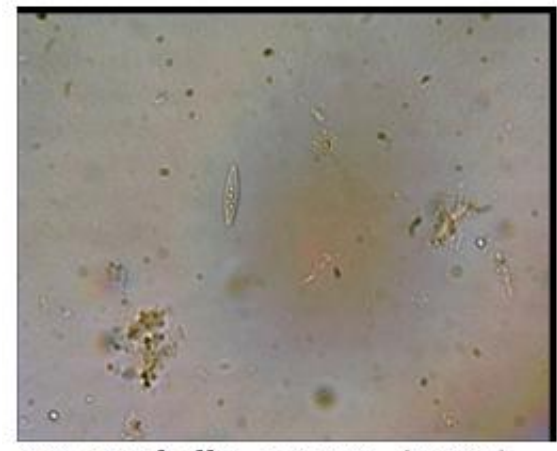

17: Cymbella minuta $(\times 600)$

Euglenophyta Algal species Identified in Kanye Reservoir

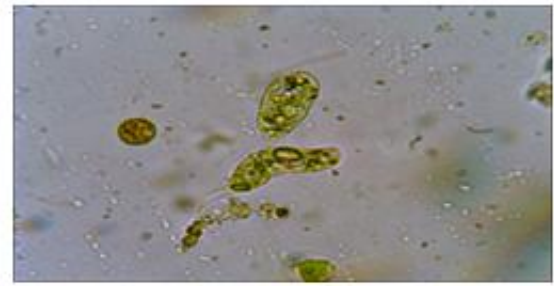

Trachelomonas spp $(\times 600)$

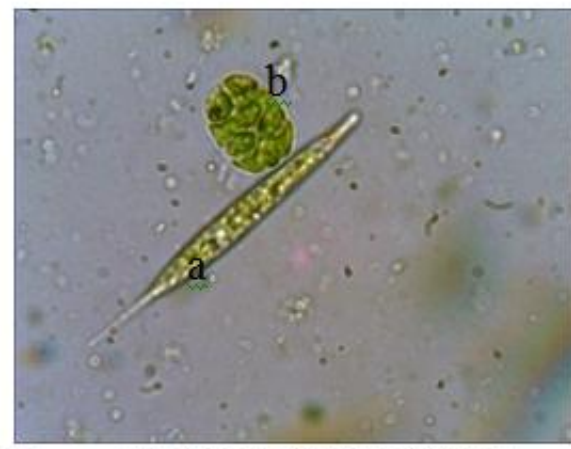

18:

(a) Synedra spp $(\times 600)$

(b) $P$. integrum

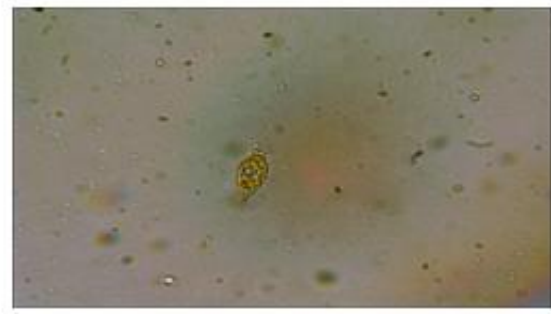

Euglena viridis $(\times 600)$

\section{Acknowledgements}

The Data have been collected from a research undertaken for purpose of the award of Masters Degree in Botany, Bayero University Kano, Nigeria and was self sponsored. We thank the staff of Bayero University Kano, Biology Laboratory Scientists, and technician of that of Pollution Control laboratory of Ministry of Environment for the use of these Laboratories. We are also greatly indebted to all guides and guards of Authors cited for their technical support and hospitality throughout the research

\section{References}

[1]. Adeniji, H.A,(1993)Study of Some Physico-chemical Factors in Reservoir in Kano State, NIFFR Annual report. pp 136-140

[2]. Antoine,S. E. and Al-Saadi, D.(1982). Studies of Periphyton of the River Wye. PhD Thesis, University College Cardiff.650pp+xxiii

[3]. American Public Health Association (1999). Standard Methods of Examination of Water and Wastewater. American Public Health Association: 20th edition Washington D.C., 1076 p.

[4]. Calgon, C. A. and Conforti, N. E (1991). Phytoplankton diversity in relation to physicochemical characteristics in Oji reservoir, Journal of Applied Science Vol:12, pp.39

[5]. Ezra, A. G. and Abdulhameed, A. (1997). Studies on algae from Four Ponds in Zaria. Proceedings of the international conference on Biotechnology for Development in Africa ,Enugu, Nigeria.pp43

[6]. Ezra, A.G, Abdulhameed, A and Sindama, A (2008) Aspects of Physico-Chemical Properties of Shadawanka River, Bauchi, Northeast Nigeria. International Journal of natural and Applied Sciences, 4(4):441-444.

[7]. Indabawa I.I and Abdullahi B.A. (2004) Ecology of fresh water phytoplankton of River Hadejia, Jigawa State Journal of Biological and Environmental Science for Tropics BUK - Nigeria (2)141-149

[8]. Kadiri M.O. (1993) Seasonal Changes in Phytoplankton Biomass of shallow Tropical Reservoir. Nigerian Journal of Botany 6:167175

[9]. Kadiri M.O. (1996) More desmids of Ikpoba Reservoir, Nigeria comparison with other African records. Algologica 80:87-98.

[10]. Kilhem P,and Hecky .R (1988).Comparative ecology of marine and fresh water phytoplankton: Immunological Oceanography 33:776-795.

[11]. Lind E.M (1968) Notes on the distribution of phytoplankton in some Kenya waters. Phycological Bulletin 3:481-493.

[12]. Needham J.G and Needham P.R. (1962) A Guide to the study of fresh water biology. Holden day-Inc. San Francisco 168pp

[13]. Offem, B.O., Samson Y. A., Omoniyi I.T., and Ipki G.U.(2009):Dynamics of the limnological features and plankton populations of Cross river system. S. E Publishers Calabar. Pp46.

[14]. Olaniyan C.I.O. (1969). The seasonal variation in the hydrology and total plankton of the lagoons of the Southern Nigeria. Nigerian Journal of Science 3(2)101-129

[15]. Patrick, R. and Riemer, C.W (1966b). Diatoms of United States 2vols. Monograph of The Academy of Natural Sciences. Exclusive of Alaska And Hawaii. Vol: 2. Part1. Monograph. Academy of Natural Science. Philadelphia. No 13. p. 213.

[16]. Prescott, G.W (1961) Algae of Western Great Lakes Area. W.M.C. Bown Company Publishers pp77-205

[17]. Renaissance Study Master Plan (1982): Ministry of Agriculture and Natural Resources Gwarzo Road Dams' irrigation scheme Kano, Nigeria pp17 
The Relative Abundance, Distribution and Species Diversity of Phytoplanktons in Kanye Dam in ..

[18]. Sigee, D.C. (2004) Freshwater Microbiology: Diversity and Dynamic Interactions of Microorganisms in the Aquatic environment. Chichester, UK, John Wiley \& Sons, p. 524

[19]. Sunda, W.G,E. Granelli and C.J. Gobler (2006). Positive feedback development and persistence of ecosystem disruptive algal blooms. Journal of Phycology 42:963-974

[20]. Underwood, G.J. and Kromkamp, J. (1999) Primary production by phytoplankton and microphytobenthos in estuaries. In Nedwell, D.B. and Raffaelli, D.G. (eds) Advances in Ecological Research. New York, Academic Press. pp. 93-153.

[21]. Watanabe, M. F., Harada, K., Carmichael, W. W., and Fujiki H. (1995). Toxic Microcystis .Boca Raton CRC Press 272pp

[22]. WHO (2003) Guidelines for Algae and Cyanobacteria in Freshwater, California, U.S.A.pp150 